\title{
Editorial
}

\section{Protecting our specialty}

T here has been a flurry of E-mails in various peer groups, regarding the issues of the proprietary right to perform various procedures, which lie at the intersection of various specialties.

Friends, there is no specialty which has a 'proprietary' right over any procedure. What someone may invent, someone else may discover. This lack of clarity on various procedures has caused a lot of heartburn, and discontent, especially with our junior colleagues, who are just entering the world of practice. They feel, and justifiably so, that after having spent so much more time and effort in training, as compared to their colleagues from a different specialty, they should have an edge, or advantage in practice. Unfortunately this is not the case, and with other disciplines being more aggressive in marketing themselves, we tend to lose out in several aspects.

There has been bitterness expressed, when senior members from our profession, lecture and demonstrate techniques in meetings of other specialties; the feeling being that they are giving an unofficial license to start performing these procedures. There have even been mails stating unequivocally that these senior members should be cautioned against accepting such invitations.

We are all aware of rapidly burgeoning clinics, aggressively marketing services which seem to avoid the nitty gritty of lengthy surgical procedures, instead highlighting quick fix, short downtime options. These come with bona fides from established organisations abroad, thus giving them an 'apparent' high class endorsement.

There is no law that can prevent this. I don't think individuals, or even associations should waste time and effort trying to stop them.

\begin{tabular}{|l|l|}
\hline \multicolumn{2}{|c|}{ Access this article online } \\
\hline Quick Response Code: & Website: \\
\hline & www.ijps.org \\
\cline { 2 - 2 } & Dol: \\
\hline
\end{tabular}

There have been laments from several members, that whenever we have dedicated workshops, concerning areas of common interest, Plastic Surgery delegates are the fewest, and most of the registrations are from other specialties. These include areas like hair restoration, cleft related surgery, craniofacial surgery, and several others. Why don't more Plastic Surgeons attend?

Do we really feel we know all there is to know about these disciplines? Are we that arrogant and self-impressed with our own qualifications and specialisations? Or are we merely complacent with our degrees and experience, and feel that these in themselves are more than enough to practise these disciplines without the need to hone skills any further?

We have spent more time and effort in the pursuit of our degrees than most other branches of medical or allied specialties. It is but natural that we resent encroachments by other specialties. However, this problem is not unique to our country. In almost every civilised nation in the world, there are parallel bodies, endorsing membership from different specialties, and giving them the leeway and license to perform many procedures, hitherto thought to be the proprietary right of the Plastic Surgeon.

What then is the solution? Is there any, or do we merely accept these limitations, and move on?

Firstly, our motto should be... 'We do it better'

Society at large gets attracted to publicity and advertising which we are poor at, but it also gets attracted to

This is an open access article distributed under the terms of the Creative Commons Attribution-NonCommercial-ShareAlike 3.0 License, which allows others to remix, tweak, and build upon the work non-commercially, as long as the author is credited and the new creations are licensed under the identical terms.

How to cite this article: Jagannathan M. Protecting our specialty. Indian J Plast Surg 2015;48:107-8. 
consistently superior results and word spreads quickly. This is our strength and we need to ensure we are better trained, better read and deliver better results with fewer complications, consistently across our membership.

Easier said than done. How do we achieve this? By ensuring we are better trained than our contemporaries from other specialties.

We are all aware that the training imparted in various centres all over the country, is of a non-uniform standard. We first need to tighten this aspect. Every chain is as strong as its weakest link. As an association, we need to look into various departments which have Plastic Surgery training, and ensure that they are brought up to standard. This will require a lot of effort and time, but in the long run it will bring dividends. We need to introspect, we need to accept our own limitations, and we need to be able to accept change.

We also need to accept that it is NOT possible to learn the entire subject in 3 years. We need to keep aside time (and money) for additional learning. However good we think we are after three years of training, we must realise that we can become better.

Secondly, as an association, we need more powers. We need to be able to speak to the regulatory authorities, one on one, and make changes. To do that, we need to be united within ourselves. There has to be credentialling regarding performance of various procedures, and this will be based on several factors. We cannot prevent anyone from performing any procedure. . . . but we can try and ensure that the law will treat us differently, in case of a mishap.

We should have committees, including ethics and legal ones, to look into various violations, and litigations by and against our members. We need to establish a code of conduct, and good medical practice guidelines. We should not hesitate to take disciplinary actions against our own members, if need be. We need to instill confidence especially among our junior members, that their parent body can do a lot of good.

In conclusion, friends, cross specialty practice is the norm, not the exception. We need to strengthen our case, by showing that we are better. Eventually we hope the law will be strong enough to weed out the unqualified people, but till then. .. we have to plod along.

\section{Mukund Jagannathan}

Editor IJPS,

Professor and Head, Department of Plastic Surgery, LTMG Hospital and LTM Medical College, Sion, Mumbai - 400 022, Maharashtra, India E-mail: editor@ijps.org 